\title{
Relative yield of wheat in coexistence with concurrent plants as indicator of competitiveness
}

\author{
Marcela Reinehr'* , Fabiane Pinto Lamego², Fernanda Cassiane Caratti', \\ Sabrina Tolloti Peruzzo', Mirian Fracasso Fabiani' , Marinês Mazzon' \\ ' Federal University of Santa Maria, Frederico Westphalen, , Brazil. ${ }^{2}$ Brazilian \\ ${ }^{2}$ Agricultural Research Corporation, Bagé, Brazil. \\ Corresponding author, e-mail: reinehr_marcela@yahoo.com.br
}

\begin{abstract}
One of the factors that limit the yield of wheat is the weed competition, being the competitive potential of plants affected by their morphophysiological characteristics. The objective of this study was to determine the competitiveness of wheat when in coexistence with Italian ryegrass (Lolium multiflorum) and radish (Raphanus sativus) competitive plants or with wheat as simulator competition plant. There were realized four experiments in the greenhouse of the Agricultural Department of Environmental Sciences of the UFSM, Campus of Frederico Westphalen - RS, during July to September, 2012. The treatments were arranged in a replacement series, in the proportions of 100:00 (wheat monoculture), 75:25, 50:50, 25:75 and 100:00 (competitor plant monoculture) for wheat plants (cv. Fundacep Cristalino) and for Italian ryegrass, radish and wheat (cv. BRS Guamirim) as competitor plants. The wheat is more competitive than Italian ryegrass in initial coexistence, even in the smallest proportion of plants. The radish when intercropped with wheat demonstrates similar competitive potential for environmental resources to the crop. There is mutual beneficial effect when wheat cultivars Fundacep Cristalino and BRS Guamirim coexisted, and each cultivar seems to have mechanism to avoid competition.
\end{abstract}

Keywords: competition, replacement series, Triticum aestivum, weed

\section{Introduction}

During the wheat cultivation cycle, there are several factors that reduce the crop yield, for example, weeds that consist in the factor of higher relation with the grain yield reduction, the failure and the profits reduction of the cultivated plants. In consequence, the use of herbicides has been prioritized. However, continuous use of this control method has selected resistant weeds (Lamego et al., 2011), requiring alternative and integrated control measures to manage these plants.

The cultural method consists in the alternative control, which aims to use characteristics of the own crop in order to minimize the impact generated by competing plants. Morphophysiological characteristics in wheat cultivars are important attributes that contribute to the definition of the competitive ability with weeds by resources available in the environment (Rigoli et al., 2009) and also contribute to reduction of the intensive use of herbicides (Balbinot Jr. et al., 2003; Fleck et al., 2009).

When crops are capable to tolerate competition with weeds, they are considered to have the ability to maintain yield even in competitive situations; or have a suppressive effect on weeds, which refers to the ability of the crop to reduce weed growth due to interference 
effect (Jannink et al., 2000).

The replacement series experiments are used to study and analyze the coexistence between weeds and crops, in order to evaluate the inter and intraspecific competition among plants (Radosevich et al., 2007). The premise of this experimental model is that the production of the crop mixture can be compared to production of the monocultures of the component crops, but without changing the space and the total population of plants (Radosevich et al., 2007).

When growing in proportional weed mixtures in replacement series, there may be advantage to both weeds and crops. In some situations in which weeds overcame crops were observed for rice grass (Echinochloa spp.) in competition with irrigated rice (Agostinetto et al., 2008); rice-red (Oryza sativa L.) competing with rice (Fleck et al., 2008); and competing with soybean (Bianchi et al., 2006) or with wheat (Rigoli et al., 2008). However, in other cases, crops were more competitive that weeds, as observed for soybean in coexistence with red rice (Moraes et al., 2009), for wheat in interaction with ryegrass (Rigoli et al., 2008). There are cases where the competitiveness is equivalent as for goose grass (Eleusine indica) in coexistence with maize (Wandscheer, 2013).

The objective of this study was to investigate the effects of relative competitiveness on wheat (Cv. Fundacep Cristalino), considering the ryegrass (Lolium multiflorum), turnip (Raphanus sativus) or own wheat (cv. BRS Guamirim) as competing plants.

\section{Material and Methods}

Four experiments were carried out in a greenhouse of the Department of Agronomic and Environmental Sciences (DCAA) of UFSM, Campus of Frederico Westphalen-RS, from June to September, 2012. The first experiment consisted of monocultures of wheat, ryegrass and turnip to determine the plant population to be established in vases, based on the "Law of the Constant Final Yield" (Radosevich et al., 2007). The populations tested were one, two, four, eight, 16, 32, 64 and 128 plants vase $^{-1}$, equivalent to $25,50,101,201$, 402, 805, 1610 and 3219 plants $\mathrm{m}^{-2}$. Vessels with capacity to $6 \mathrm{~L}$ and $22.5 \mathrm{~cm}$ in diameter, filled with agricultural substrate (Tecnomax®) were used. After the interpretation of the data by method of the reciprocal yield per plant to determine the dry shoot mass (DSM) constant (data not shown), was established a proper population of 32 plants vase $^{-1}$ (equivalent to 805 plants $\mathrm{m}^{-2}$ ).

The other experiments were conducted in a replacement series. Each of the replacement series was composed of proportions of wheat (cv. Fundacep Cristalino) and ryegrass (Experiment II); wheat (Cv. Fundacep Cristalino) and turnip (Experiment III); wheat and wheat (Experiment IV), comparing cultivars with contrasting plant characteristics (Fundacep Cristalino (medium and precocious) $x$ BRS Guamirim (low and precocious)). The proportions of plants were: 100:0 (wheat monoculture); 75:25; 50:50; 25:75 and 100:0\% (monoculture of the competing plant), according to methodology described by Radosevich et al. (2007).

The experimental units were arranged in a completely randomized design (CRD), with four replications. At 28 days after emergence (DAE) the shoot was collected to determine the DSM of wheat and competing plants. For the interpretation of DSM, the method proposed by Radosevich et al. (2007), which uses graphical analysis of the relative yield or conventional method for replacement experiments, and a diagram based on the relative yield (RP) and total relative yield (TRP), in the proportions of adopted plants of $0,25,75$ and $100 \%$ of wheat and competing plants.

The calculation of the difference between the hypothetical line and the observed values for RP, TRP and for the competitiveness indexes (CR, $K$ and $A$ ) was made by the equations proposed by Hoffman \& Buhler (2002). The obtained RP was given by the production for each population and proportion divided by the mean production of monoculture for that population. The RP equation was obtained by the ratio between the mean mass accumulation of the mixture and the average of the monoculture: $\mathrm{RPa}=(\mathrm{p}) \times($ Amix $/$ Amon), relative to the yield obtained by crop (a); $\mathrm{RPb}=(1-\mathrm{P}) \times($ Bmix / Bmon), relative to the yield obtained by the competing species (b).

The TRP is represented by the sum of the relative yields of the crop and the competitor in 
the respective proportions of plants: $T R P=R P a+$ $\mathrm{RPb}$, where RPa refers to the relative yield for the crop and $\mathrm{RPb}$ refers to the relative yield of the competing species. When the TRP equals 1 (one), it indicates that the competition of resources between species was equivalent; when greater than 1 (one), competition was avoided and; when the value is minor than 1 (one), the species are antagonistic and there is mutual loss.

The data obtained was analyzed for homoscedasticity, using the Bartlett, Levene and Brow-Forsythe tests and, if necessary, data transformations were performed. Regarding the statistical analysis of the relative yield, the differences for the RP (DRP) values obtained in the proportions of 25,50 and $75 \%$ of plants that were calculated first with respect to the hypothetical values belonging to lines in the respective proportions: $0.25 ; 0.50$ and 0.75 (Fleck et al., 2008; Rigoli et al., 2008; Dal Magro et al., 2011; Wandscheer et al., 2013). The 5\% probability of error test was used to test the DRP, RPT, CR, K and $A$ indexes for hypothetical lines (Hoffman \& Buhler, 2002; Fleands et al., 2008; Wandscheer et al., 2013).

The null hypotheses to test the differences of DRP and A was that the means were equals to zero $(\mathrm{HO}=0)$; for RPT and $\mathrm{CR}$, that the means were equal to one $(\mathrm{HO}=1)$; and for $\mathrm{K}$ index, that the means of the differences between $\mathrm{Ka}$ and $\mathrm{Kb}$ were equals to zero $[\mathrm{HO}=(\mathrm{Ka}-\mathrm{Kb})=0]$ (Moraes et al., 2009; Wandscheer et al., 2013). The DSM variable was expressed as mean value per plant and submitted to analysis of variance. The mean values of the treatments were compared by the Dunnett test ( $p \leq 0.05$ ), where the monocultures were considered as the control treatments (Moraes et al., 2009; Wandscheer et al., 2013).

\section{Results and discussion}

There was interaction between the species and the same ones competed for the same resources available in the middle, and wheat was more competitive compared to ryegrass, with higher DSM accumulation (Figure 1). When the ryegrass was submitted to the initial coexistence with wheat (up to 28 DAE) suffered losses in the production of DSM. The RP of DSM from Fundacep Cristalino was represented by a convex line, while ryegrass was represented by a concave line, so it can be inferred that ryegrass had a negative effect when in competition with wheat, and the same was not observed for wheat.

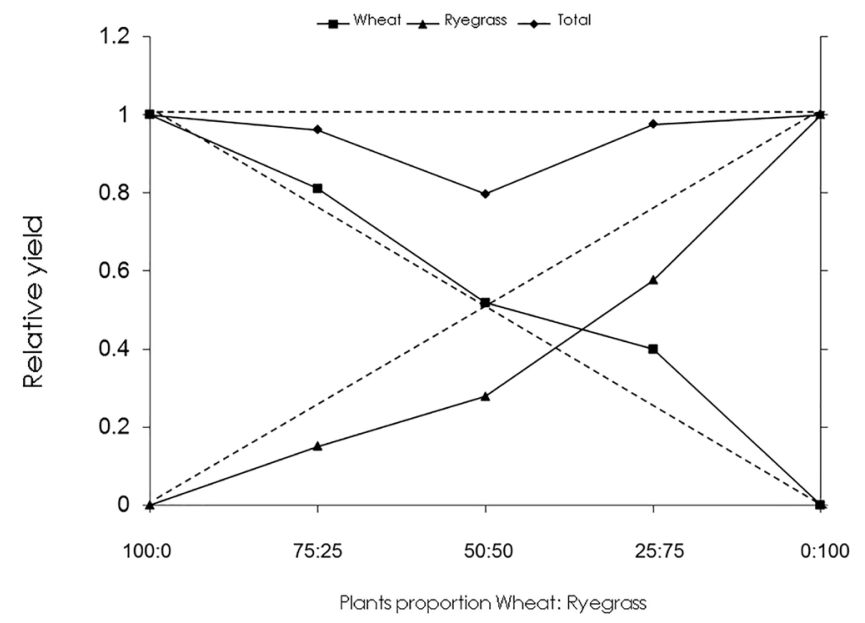

Figure 1. Relative yield (RP) and total yield (TP) for shoot dry matter of of wheat and ryegrass. UFSM, Campus de Frederico Westphalen - RS, 2012.

The RP deviations from the DSM accumulation of wheat (CV. Fundacep Cristalino), when compared to the respective hypothetical lines, were significant only in the proportion of 25:75 plants (wheat x ryegrass). For ryegrass RP, all proportions presented significant differences in relation to the hypothetical line (Table 1).
The TRP presented statistically significant differences only for the proportion of 50:50 plants, with values lower than 1 (one), indicating that there was damage for both species regarding the accumulation of DSM (Table 1). There was demand for the species at a similar time for some of the resources available in the middle, configuring competition between wheat and 
Table 1. Relative yield differences for the shoot dry matter variable and total relative yield (TRP), in the proportions of $75: 25,50: 50$ and $25: 75$ of wheat plants in competition with ryegrass, turnip and wheat simulating competing plant (cv. BRS Guamirim). UFSM, Campus de Frederico Westphalen - RS, 2012.

\begin{tabular}{lccc}
\hline \multicolumn{4}{c}{ Proportion of plants (wheat:competitor) } \\
\hline \multicolumn{4}{c}{ Shoot dry matter } \\
\hline Wheat & $75: 25$ & $50: 50$ & $25: 75$ \\
Ryegrass & $0.06( \pm 0.03)^{\text {ns }}$ & $0.02( \pm 0.04)^{\text {ns }}$ & $0.15( \pm 0.02)^{*}$ \\
TRP & $-0.10( \pm 0.01)^{*}$ & $-0.22( \pm 0.04)^{*}$ & $-0.17( \pm 0.05)^{*}$ \\
\hline Wheat & $0.96( \pm 0.04)^{n s}$ & $0.80( \pm 0.08)^{*}$ & $0.98( \pm 0.06)^{\text {ns }}$ \\
Turnip & $-0.10( \pm 0.05)^{*}$ & $-0.04( \pm 0.03)^{*}$ & $-0.07( \pm 0.01)^{*}$ \\
TRP & $0.04( \pm 0.06)^{*}$ & $-0.14( \pm 0.10)^{*}$ & $-0.31( \pm 0.12)^{*}$ \\
Wheat CV. Fundacep Crystalline & $0.94( \pm 0.10)^{*}$ & $0.81( \pm 0.12)^{*}$ & $0.62( \pm 0.11)^{*}$ \\
Wheat CV. BRS Guamirim & $0.27( \pm 0.09)^{*}$ & $0.30( \pm 0.14)^{*}$ & $0.18( \pm 0.05)^{*}$ \\
TRP & $-0.01( \pm 0.04)^{\text {ns }}$ & $0.07( \pm 0.08)^{\text {ns }}$ & $0.13( \pm 0.12)^{*}$ \\
ns Not significant and * significant by the test tat the level of 5\% error probability . Values in parentheses represent the standard error of the mean.
\end{tabular}

ryegrass, especially when the species occur in same population.

The interactions among the species evaluated indicate antagonism or competition (Radosevich et al., 2007), since both species presented higher losses when the population was equivalent $(50: 50)$, as the population in which the weed occurs and the morphological characteristics of weeds are a determinant factor in the demand and dispute over resources (Bianchi et al, 2006). Wheat was more competitive than ryegrass when the species were submitted to the conditional competition (Rigoli et al., 2008). The behavior of the competing ryegrass species is related to their slow initial development and to the high initial vigor presented by the Fundacep Cristalino wheat cultivar, since the speed of emergence is a determining factor in the competitive ability of the species.
The use of inadequate densities in crop sowing may promote intraspecific competition, affecting the maintenance of plant structures. This fact may help explain the behavior of the crop in relation to its higher accumulation of DSM in its lowest proportion (25:75) (Table 1). It is believed that the lower accumulation of DSM for wheat in relation to the hypothetical line for the 75:25 and 50:50 ratios (wheat x ryegrass) compared to the greater accumulation observed in the 25:75 ratio may be correlated to the dispute by the resources between the culture itself, showing that intraspecific competition may be more harmful than interspecific competition, depending on the plants density.

When the wheat coexisted with the turnip, the culture also suffered interference in the DSM by the turnip as a competing species (Figure 2).

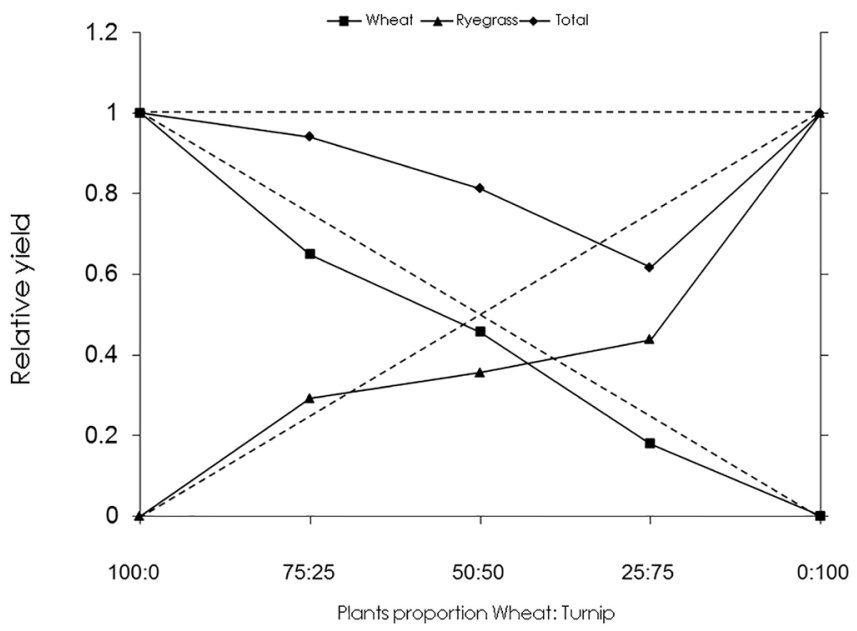

Figure 2. Relative (RP) and total (TRP) Productivities for shoot dry matter of wheat and turnip. UFSM, Campus de Frederico Westphalen - RS, 2012. 
For the turnip, it was observed a significant reduction in the accumulation of DSM. The cultivar Fundacep Cristalino and the turnip presented significant differences for RP in the proportions of plants of $25: 75 ; 50: 50$ and $75: 25$ (Table 1). Also in this case, the TRP presented values lower than 1 (one), indicating that the turnip also competed, in a tight way with the wheat by means resources (Table 2).

This result allows us to infer that when the culture and the competing plant emerge occur simultaneously, as observed in the present study, even presenting distinct morphophysiological characteristics, they have similar demand for the basic resources necessary for their initial development.

Table 2. Indices of competitiveness between wheat cv. Fundacep Cristalino and competitors (ryegrass, turnip or wheat cv. BRS Guamirim), expressed by relative competitiveness (RC) relative grouping (K) and aggressiveness (A) coefficients. UFSM, Campus de Frederico Westphalen - RS, 2012.

\begin{tabular}{|c|c|c|c|c|}
\hline & $\mathrm{RC}$ & $K_{\text {wheat }}$ & $\mathrm{K}_{\text {competitor }}$ & A \\
\hline & \multicolumn{4}{|c|}{ Shoot dry matter } \\
\hline Ryegrass & $1.90( \pm 0.15)^{*}$ & $1.14( \pm 0.23)$ & $0.40( \pm 0.08)^{*}$ & $0.24( \pm 0.02)^{*}$ \\
\hline Turnip & $1.72( \pm 0.52)^{\mathrm{ns}}$ & $0.86( \pm 0.10)$ & $0.71( \pm 0.34)^{\mathrm{ns}}$ & $0.10( \pm 0.10)^{\mathrm{ns}}$ \\
\hline Wheat & $1.39( \pm 0.15)^{\mathrm{ns}}$ & $1.06( \pm 4.17)$ & $1.80( \pm 0.83)^{\mathrm{ns}}$ & $0.23( \pm 0.08)^{n s}$ \\
\hline
\end{tabular}

Turnip is an important weed in the wheat production system, since it presents rapid initial growth and expressive development of the shoots, besides a well developed root system. Thus, it exerts a negative effect on wheat, even though it is not morphologically similar to the crop. For two soybean cultivars tested by Bianchi et al. (2006), the turnip also exerted strong competition pressure in the vegetative phase of the crop (42 $D A E)$, being the interference of the weed on the cultivars superior to the interference that the cultivars exerted on the turnip.

In the present study, the wheat cultivar Fundacep Cristalino (precocious and medium size) showed a competitive potential similar to that of weed, since, even in its lowest proportion (25:75), the wheat cultivar was able to reduce accumulation of DSM by the turnip competing plant. However, the results observed for the interactions between wheat (cv. Fundacep Cristalino) and turnip in this work are not corroborated by results found by Rigoli et al. (2008), when wheat cv. Fundacep 52 (early cycle and low size) was submitted to coexistence with turnip; in this case, the weed species was more competitive than the crop. The graphical analysis of the results obtained for RP of the DSM indicated that there were benefits for the wheat cultivar Fundacep Cristalino when it was kept in common with wheat BRS Guamirim in initial development period (28 DAE). In Figure 3, a convex line is observed for the performance of Fundacep Cristalino regarding the accumulation of DSM.

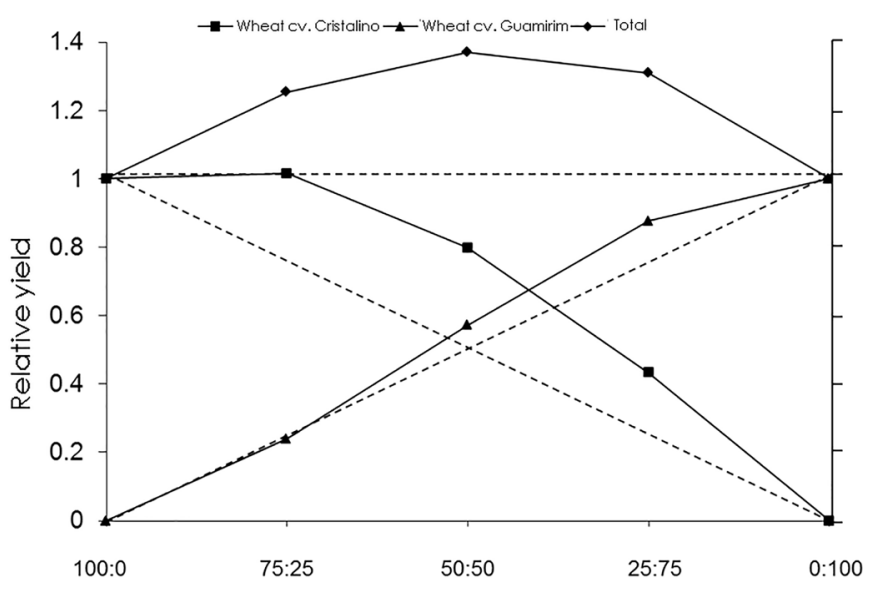

Plants proportion Wheat cv Cristalino: Eheatcv Guamirim

Plants proportion Wheat cv. Cristalino: Eheat cv. Guamirim
Figure 3. Relative (RP) and total (TRP) Yield for shoot dry matter of wheat cv. Fundacep cristalino and wheat cV. BRS Guamirim (simulador). UFSM, Campus de Frederico Westphalen - RS, 2012. 
Wheat cV. BRS Guamirim did not present significant differences for RP in the lowest proportion of plants $(75: 25)$ and in the equivalent proportion (50:50), with DSM accumulation of the significant competing plant only in its highest proportion (25:75) (Table 1). Likewise, the TRP also provided performance in such a way that the corresponding line presented convex concordance (Figure 3) and values greater than 1 (one) (Table 1), inferring that competition was avoided, with no losses for both species, and these benefited by the coexistence.

It is probable that the wheat cultivars in question, when kept in an initial coexistence, avoided the competition for the basic elements, resulting in an increase in the TRP for the accumulation of DSM (Figure 3). The initial growth of the Fundacep Cristalino and BRS Guamirim wheat cultivars provided a mutually beneficial effect. In this case, it could be inferred that the resources of the medium were not limiting.

In general, the DSM of TRP for wheat and ryegrass replacement series presented a significant reduction when in the proportion of plants equivalent to 50:50; wheat and turnip presented significant values, being positive (higher than one) when wheat cultivars grew under interference from one another; and negative (values lower than one) when wheat cv. Fundacep Cristalino was kept in competition with the turnip.

The values that compose the TRP line were lower than one, assuming the concave shape, which infers mutual losses when living with weeds. When values greater than one are obtained, there is a convex line, which indicates that competition is avoided by the supply of resources, demand overcoming or because the species in question have a differentiated demand for the resources of the environment, and both species in contribute to the increase in TRP (Radosevich et al., 2007). This effect was observed when the replacement series was composed by the two wheat cultivars.

For competitive indexes, competitive superiority is considered when at least two indices are significant (Bianchi et al., 2006). Superior CR was observed for wheat compared to ryegrass competitor species; the dominance of wheat over ryegrass was also significant, where $\mathrm{K}_{\text {wheat }}$ was statistically superior to $\mathrm{K}_{\text {ryegrassi }}$; wheat showed greater "aggressiveness" to ryegrass (Table 2), which confirms a higher competitive ability of wheat $c v$. Fundacep Crystalline compared to weed species when in equal proportion of plants.

When comparing the 50:50 ratio for wheat and turnip or wheat cr. BRS Guamirim, there was no significant difference for $C R$ index; $K$ and $A$ (Table 2). This shows that no higher growth, nor dominance, has been observed, so little greater "aggressiveness" of one species in relation to the other, which allows us to infer that both plants competed with each other with the same intensity.

The greater competitiveness expressed by the Fundacep Cristalino wheat crop (median height) is in agreement with the results obtained by Rigoli et al. (2008) who worked with Fundacep 52 (low stature) and Fundacep Horizonte (medium / high stature) wheat cultivars, respectively, which were also more competitive than ryegrass in the proportion of 50:50 plants.

The initial coexistence between wheat and ryegrass provided a significant reduction of DSM for ryegrass in the proportions of 50:50 and 25:75 when compared to the control (0: 100). As for wheat, this only differed from the control (100:0) in the lowest proportion (25:75), where DSM increased (Table 3). When grown under competition with turnip, wheat $\mathrm{cv}$. Fundacep Cristalino, did not present significant differences regarding the accumulation of DSM in relation to its respective control (Table 3).

The competing turnip plant submitted to wheat interference showed a significant reduction for the accumulation of DSM in the proportions 75:25 and 50:50 (Table 3). When wheat cv. Fundacep Cristalino was submitted to coexistence with wheat cV. BRS Guamirim, the first presented greater accumulation of DSM compared to its control, when cultivated to a lesser extent (25:75). The BRS Guamirim wheat cultivar did not present a significant difference in relation to the control (Table 3).

It was found that the interspecific competition for wheat and intraspecific for ryegrass were the most expressive. This is because the highest average per plant of the crop for 
shoot dry matter was observed when it was in a population smaller than that of the competitor (25:75). A similar result is observed when wheat competes with the own wheat as a concurrent plant simulator; in this case, cv. Fundacep Cristalino again presents higher average per plant for the variable when in a lower proportion than the $c v$. BRS Guamirim, as simulator of competing plant. When the wheat was in coexistence with the turnip, there was no significant difference. For the turnip, interspecific competition was the most expressive.

Interpreting at the same time the values obtained for RP of the DSM and the competitiveness indexes, the Fundacep Cristalino wheat cultivar presents good competitive ability, since its performance was superior to that of the ryegrass species, one of the main

Table 3. Response of the Wheat cV. Fundacep Cristalino to competitor interference (ryegrass, turnip or wheat BRS Guamirim), 28 days after emergence. UFSM, Campus de Frederico Westphalen - RS, 2012.

\begin{tabular}{|c|c|c|c|c|c|c|}
\hline \multicolumn{7}{|c|}{ Proportion of plants (wheat: competitor) } \\
\hline & 100:0 (C) & 75:25 & $50: 50$ & $25: 75$ & $0: 100(T)$ & C.V. $(\%)^{1}$ \\
\hline \multicolumn{7}{|c|}{ Shoot dry matter } \\
\hline Wheat & 0.48 & $0.52^{\text {ns }}$ & $0.50^{\mathrm{ns}}$ & $0.77^{*}$ & - & 13.94 \\
\hline Ryegrass & - & $0.12^{\text {ns }}$ & $0.08^{*}$ & $0.09 *$ & 0.15 & 25.76 \\
\hline Wheat & 0.29 & $0.24^{\mathrm{ns}}$ & $0.26^{\text {ns }}$ & $0.22^{\text {ns }}$ & - & 17.70 \\
\hline Turnip & - & $0.45^{*}$ & $0.41^{*}$ & $0.63^{\text {ns }}$ & 0.78 & 14.19 \\
\hline Wheat cv. Cristalino & 0.20 & $0.26^{\mathrm{ns}}$ & $0.31^{\mathrm{ns}}$ & $0.34^{*}$ & - & 12.47 \\
\hline Wheat cv. Guamirim & - & $0.29 \mathrm{~ns}$ & $0.35^{\mathrm{ns}}$ & $0.36^{\mathrm{ns}}$ & 0.30 & 13.83 \\
\hline
\end{tabular}

competing plants of the culture, and maintained competitive with the common turnip and wheat cV. BRS Guamirim, as a simulator of competing species.

A similar study was carried out to evaluate the competitive behavior of wheat with ryegrass and turnip (Rigoli et al., 2008); however, the competitive ability of a species may vary according to the morphophysiological characteristics of the cultivars (Balbinot Jr. et al., 2003; Fleck et al., 2008). In the present study, the cultivar Fundacep Cristalino of early and medium cycle was superior to the turnip differently from the Fundacep 52 cultivar, early cycle and low size as studied by Rigoli et al. (2008). Therefore, the results obtained here highlight the importance of the plant characteristics of the cultivar in the competitive success with the weeds.

\section{Conclusions.}

The wheat, cultivar Fundacep Cristalino, is more competitive than ryegrass when in initial coexistence, even in the lowest proportion of plants.

Turnip, when growing together with wheat, cultivar Fundacep Cristalino until 28 DAE, demonstrates competitive potential for the resources of the medium in a similar way to culture.
The initial joint growth of the Fundacep Cristalino and BRS Guamirim wheat cultivars, provides mutual beneficial effect, where each species seems to present an escape mechanism to avoid competition.

\section{Acknowledgements}

To the researcherMario Antônio Bianchi of CCGL Tec and to the Embrapa Trigo for providing the seeds used in the research; to Capes, CNPq and Fapergs by the scientific research and the masters scholarships (PPPGAAA/UFSM).

\section{References}

Agostinetto et al., 2008. Período crítico de competição de plantas daninhas com a cultura do trigo. Planta Daninha. 26: 271-278.

Balbinot Júnior et al., 2003. Características de plantas de arroz e a habilidade competitiva com plantas daninhas. Planta Daninha. 21: 165-174.

Bianchi et al., 2006. Proporção entre plantas de soja e plantas competidoras e as relações de interferência mútua. Ciência Rural. 36: 1380-1387.

Dal Magro et al., 2011. Habilidade competitiva entre biótipos de Cyperus difformis L. resistente ou suscetível a herbicidas inibidores da ALS e destes com arroz irrigado. Bragantia. 70: 294-30.

Fleck et al., 2008. Competitividade relativa entre cultivares de arroz irrigado e biótipo de arrozvermelho. Planta Daninha. 26: 101-111. 
Reinehr et al. (2018) / Relative yield of wheat...

Fleck et al., 2009. Associação de características de planta em cultivares de aveia com habilidade competitiva. Planta Daninha. 27: 21 1-220.

Hoffman \& Buhler. 2002. Utilizing Sorghum as a functional model of crop-weed competition. I. Establishing a competitive hierarchy. Weed Science. 50: 466-472.

Jannink et al. 2000. Index selection for weed suppressive ability in soybean. Crop Science. 40:1087-1094.

Lamego, F. P., Vidal, R. A., Burgos, N. R. 2011. Competitiveness of ALS inhibitors resistant and susceptible biotypes of greater beggarticks (Bidens subalternans). Planta Daninha. 29: 457464.

Moraes et al. 2009. Competitividade relativa de soja com arroz-vermelho. Planta Daninha. 27: 3540.

Radosevich et al. 2007. Ecology of Weeds and Invasive Plants. Wiley, New York, USA. 472p.

Rigoli et al., 2008. Habilidade competitiva relativa do trigo (Triticum aestivum) em convivência com azevém (Lolium multiflorum) ou nabo (Raphanus raphanistrum). Planta Daninha. 26: 93-100.

Rigoli $\dagger$ al., 2009. Potencial competitivo de cultivares de trigo em função do tempo de emergência. Planta Daninha. 27: 41-47.

Wandscheer et I., 2013. Competitive ability of corn in coexistence with goosegrass. Planta Daninha.31: 281-289. 